\title{
Growth and Earnings Persistence in Banking Firms: A Dynamic Panel Investigation
}

\author{
Choudhry Tanveer Shehzad \\ Jakob De Haan \\ Bert Scholtens
}

\author{
CESIFO WORKING PAPER NO. 2772 \\ CATEGORY 7: MONETARY POLICY AND INTERNATIONAL FINANCE
}

August 2009
An electronic version of the paper may be downloaded
- from the SSRN website:
- from the RePEc website:
- from the CESifo website:




\title{
Growth and Earnings Persistence in Banking Firms: A Dynamic Panel Investigation
}

\begin{abstract}
This paper investigates (i) whether growth and profitability persist in banking firms, (ii) whether the level and volatility of growth and profitability are bank-size dependent, and (iii) the relationship between growth and profitability of a bank. Using a dynamic panel model estimated by GMM for a mixed sample of more than 1500 banks from 65 countries, we find no evidence of persistence in bank growth. However, our findings suggest significant persistence in bank profitability. Moreover, our results show that the growth and profitability dynamics of banks based in OECD countries differ from those of banks in non-OECD countries.
\end{abstract}

JEL Code: G21, G32, L25.

Keywords: bank size, bank earnings, earnings volatility, bank risk, Gibrat's law.

Choudhry Tanveer Shehzad Faculty of Economics and Business University of Groningen PO Box 800 9700 AV Groningen

The Netherlands c.t.shehzad@rug.nl
Jakob De Haan

Faculty of Economics and Business

University of Groningen

PO Box 800

9700 AV Groningen

The Netherlands

jakob.de.haan@rug.nl

\author{
Bert Scholtens \\ Faculty of Economics and Business \\ University of Groningen \\ PO Box 800 \\ 9700 AV Groningen \\ The Netherlands \\ l.j.r.scholtens@rug.nl
}

17 August 2009

The authors are thankful to participants in the European Banking Symposium, 2009, held in Maastricht, Netherlands, for their valuable comments. Any errors are the responsibility of the authors. 
Does firm growth depend on firm size and is firm growth persistent? Although there are many studies analyzing these questions for non-banking firms, there are only few papers that focus on banking firms. Still, these issues are important for the banking sector as well. For instance, persistence of high growth rates of banking firms would result in a highly concentrated banking industry.

The literature on this topic has been significantly influenced by Gibrat’s (1931) 'Law of Proportionate Effect'. The strong version of Gibrat's 'law' consists of three propositions: (i) the growth rate of each firm over some period is independent of its size; (ii) the variability of a firm's growth rate is independent of the firm's size, and (iii) the firm's growth rates in two consecutive periods are independent of each other. Together these propositions imply that the firm's growth rate follows a random walk. The most extensive work to date on Gibrat's 'law' for banking firms are the studies by Goddard et al. (2004a, 2004b). These authors not only examined Gibrat's 'law', but also analyzed the relationship between bank growth and profitability. The two indicators of bank performance are obviously related. Retained earnings are, for instance, a principal source of capital and in a regulatory system requiring banks to meet various capital adequacy requirements profit therefore enables the expansion of a bank's portfolio of risky assets.

This paper investigates the interactions between firm growth and profitability, using a data set comprising more than 1500 banks located in 65 countries. We examine the following questions: (i) Are growth and earnings patterns in banking firms persistent? (ii) Are growth and earnings affected by bank size? (iii) Are growth volatility and earnings volatility affected by bank size? and (iv) What is the relationship between bank earnings and bank growth? Growth and profit rates are observed annually over the period 1997 to 2000, together with a set of control variables that capture the impact of firmlevel, industry-level, and macroeconomic variables. Dynamic panel regressions are used to estimate growth and profit equations following the approach of Blundel and Bond (1998).

Our results suggest that bank growth is not persistent, in contrast to bank profitability. The latter finding is in contrast to the results reported by Goddard et al. (2004a,b). Additionally, we find that large banks in OECD economies grow at a slower 
speed than smaller banks, but bank size does not influence bank growth in non-OECD economies.

This paper extends previous work like that of Tschoegl (1983), Hameeteman and Scholtens (2000), Goddard et al. (2004a, 2004b), Athanasoglou (2005) and Benito (2008) in four directions. First, we examine a much bigger data set consisting of more than 1500 banks from 65 countries for the period 1997-2007. Second, our dataset includes banks from various non-OECD economies, whereas previous research employed data for banks in OECD countries. Third, we focus on recent data. Using more recent data may lead to different results because the structure of the banking industry significantly changed also in OECD countries between 1997 and 2007, as we will show in our data section. Finally, the most recent papers in this area use the Arellano and Bond (1991) procedure for estimating dynamic panel models. However, Blundell and Bond (1998) show that in panels with a limited time period and many banks the Arellano and Bond (1991) approach produces biased estimates. Therefore, we apply an alternative methodology suggested by Blundell and Bond (1998). Additionally, we extend the list of control variables.

The remainder of the paper is structured as follows. Section 1 discusses the literature on bank growth and bank earnings and develops our model. Section 2 describes our data on bank growth, profitability, and size distribution. Section 3 presents the estimation results for the full sample, whereas section 4 examines differences between OECD and non-OECD countries. Section 5 concludes the paper.

\section{BANK GROWTH AND EARNINGS PATTERNS}

Tschoegl (1983) tested Gibrat's 'Law of Proportionate Effect' for the 100 largest banks of the world from 1969 to 1977 and concludes that the growth rate of these banks is independent of their size. However, the variability of bank growth rate declines with an increase in bank size. Additionally, he does not find any clear results regarding the relationship between bank growth rates in two consecutive periods. More recently, Benito (2008) tested Gibrat's 'law’ for Spanish banks using panel unit root tests and finds that 
the size-growth relationship is not stable over time but depends on the competitive environment.

Research on Gibrat's 'law' originally focused on growth, while a separate strand of the literature examined the linkage between size and profitability in banking. These studies focused on profitability and not on the persistence and dynamics of earnings. For instance, analyzing the effect of bank size on bank performance, Stein (2002) and Berger et al. (2005) report that small banks have better abilities to allocate capital and to collect and act on 'soft' information regarding their borrowers. However, Stever (2007) finds lower betas for small banks and attributes this result to lower firm diversification. Some papers do not identify a strong link between market structure and profitability. For instance, Athanasoglu et al. (2005) study the effect of bank-specific, industry-specific, and macroeconomic determinants of bank profitability using the GMM technique for a panel of Greek banks covering the period 1985-2001. They find that all bank-specific determinants, except for size, affect bank profitability significantly in the anticipated way.

Goddard et al. (2004a, 2004b) combine both strands of the literature. They use panel and cross-sectional regressions to estimate growth and profit models for a sample of almost 600 banks from five European Union countries over the period 1992-1998. The authors find that profit is an important prerequisite for future growth. When banks become larger, their growth performance tends to improve further. Finally, growth persistence tends to be higher for savings and co-operative banks than for commercial banks.

The model tested by Goddard et al. (2004b) to examine the linkages between bank size, growth, and profitability provides an interesting framework. We therefore take this model as our starting point, but will introduce some adjustments for econometric and theoretical reasons. Bank growth will follow a random walk with drift if all the three propositions of Gibrat’s ‘law’ hold:

$$
S_{i t}-S_{i t-1}=\alpha_{i}+\delta_{t}+\varepsilon_{i t}
$$

Where $S_{i t}$ indicates the $\log$ of the size of bank $i$ in year $t, S_{i t-1}$ indicates the log of the size of bank $i$ in year $t-1$, and $\alpha_{i}+\delta_{t}+\varepsilon_{i t}$ indicates that logarithmic bank growth follows a random walk with drift where $\alpha_{i}+\delta_{t}$ are individual bank and time effects, respectively. 
We can rewrite equation (1) as follows:

$$
S_{i t}-S_{i t-1}=\alpha_{i}+\delta_{t}+(\beta-1) S_{i t-1}+\varepsilon_{i t}
$$

Where parameter $\beta$ indicates the relationship between the log of bank size and annual growth. To examine the effect of growth in the previous period, we introduce a lagged dependent variable in the model:

$$
S_{i t}-S_{i t-1}=\alpha_{i}+\delta_{t}+(\beta-1) S_{i t-1}+\gamma\left(S_{i t-1}-S_{i t-2}\right)+\varepsilon_{i t}
$$

Using this model, we can test our first three hypotheses. The first hypothesis is:

\section{Hypothesis 1: Bank growth is independent of bank size}

To examine the effect of bank size on growth, we test the following hypothesis:

$$
\begin{aligned}
& H_{0}: \beta-1=0 \\
& H_{1}: \beta-1 \neq 0
\end{aligned}
$$

The null hypothesis corresponds to Gibrat's proposition that the growth rate of each bank is independent of its size. If $\beta>1$, i.e. bigger banks grow faster, concentration will increase and the distribution of bank sizes will become highly skewed.

\section{Hypothesis 2: Bank growth variability is independent of bank size}

To test this proposition, we need to examine whether banks are homogeneous, i.e. individual banks effects $\left(\alpha_{i}\right)$ are the same and do not vary with bank size.

$$
\begin{aligned}
& H_{0}: \alpha_{i}=\alpha \\
& H_{1}: \alpha_{i} \neq \alpha
\end{aligned}
$$

The null hypothesis corresponds to Gibrat's second proposition and indicates that bank size does not affect growth volatility. To test this hypothesis we plot residuals from our models against bank size and check if there is any systemic variation in residuals with different bank size. ${ }^{1}$

\footnotetext{
${ }^{1}$ A satisfactory testing procedure for this hypothesis for dynamic panel models with small $T$ and large $N$ samples is not available. The test recently proposed by Sarfidis et al. (2009) is also not suitable here
} 


\section{Hypothesis 3: Bank growth is not persistent}

To examine the persistence of bank growth, we test the following hypotheses:

$$
\begin{aligned}
& H_{0}: \gamma=0 \\
& H_{1}: \gamma \neq 0
\end{aligned}
$$

The third null hypothesis corresponds to Gibrat's third proposition and indicates that current growth does not depend on past growth.

Goddard et al. (2004b) extend equation (3) by adding lagged profit as an explanatory variable:

$$
S_{i t}-S_{i t-1}=\alpha_{i}+\delta_{t}+(\beta-1) S_{i t-1}+\gamma\left(S_{i t-1}-S_{i t-2}\right)+\varphi \prod_{i t-1}+\varepsilon_{i t}
$$

where $\prod_{i t-1}$ indicates profit of bank $i$ in year $t$-1. Using this extended model, we can test our fourth hypothesis about the linkage between profitability and bank growth.

\section{Hypothesis 4: Bank profitability has no effect on bank growth}

To analyze the effect of bank profitability on growth, we test

$$
\begin{aligned}
& H_{0}: \varphi=0 \\
& H_{1}: \varphi \neq 0
\end{aligned}
$$

We include various control variables that will be explained in some detail in the next section. The model therefore becomes:

$$
S_{i t}-S_{i t-1}=\alpha_{i}+\delta_{t}+(\beta-1) S_{i t-1}+\gamma\left(S_{i t-1}-S_{i t-2}\right)+\varphi \prod_{i t-1}+\zeta X_{i t}+\varepsilon_{i t}
$$

where $X_{i t}$ is a matrix of control variables for bank $i$ in year $t$.

As long as banks are homogeneous, i.e. $\alpha_{i}=\alpha$, this specification gives unbiased estimates of the model by pooling the data. However, if banks are not homogeneous, because we are interested in the variation of residuals against bank size and not the cross sectional dependence itself. 
Breitung and Meyer (1994) show that $(\beta-1)$ becomes a biased and inconsistent estimator. Instead they suggest transforming equation (5) as follows:

$$
S_{i t}-S_{i t-1}=(\beta-1)\left(S_{i t-1}-S_{i 0}\right)+\gamma\left(S_{i t-1}-S_{i t-2}\right)+\varphi \prod_{i t-1}+\zeta X_{i t}+\xi_{1 i t}
$$

where $\xi_{1 i t}=\alpha_{i}+\varepsilon_{i t}+\beta S_{i 0}$. This provides an unbiased and consistent estimation of our model. In equation (6), instead of taking the lagged size as the explanatory variable, we take the difference of lagged size and initial bank size. Breitung and Meyer (1994) show that after this transformation $(\beta-1)$ is not affected by heterogeneity.

Now we have derived our model for bank growth. By following the same steps, we can derive our model for profitability. So equation (7) below gives the model for the dynamic analysis of profitability:

$$
\prod_{i t}=\left(\beta_{\pi}-1\right)\left(\prod_{i t-1}-\prod_{i 0}\right)+\gamma_{\pi}\left(S_{i t-1}-S_{i t-2}\right)+\zeta_{\pi} X_{i t}+\xi_{\pi 2 i t}
$$

where $\xi_{\pi 2 i t}=\alpha_{\pi i}+\varepsilon_{\pi i t}+\beta_{\pi} \prod_{i 0}$. This model will be used to test hypotheses 1-4 using profitability instead of bank growth as dependent variable.

Arellano and Bond (1991) show that due to the presence of individual bank effects and the lagged dependent variable, OLS or fixed effects models cannot be used for estimating equations (6) and (7). Goddard et al. (2004a; 2004b) therefore use the difference Generalized Method of Moments (GMM) approach as suggested by Arellano and Bond (1991). However, Blundell and Bond (1998) show that if the dependent variable is close to a random walk, the difference GMM approach performs poorly, because past levels convey little information about future changes. Blundell and Bond (1998) suggest transforming the differences of the regressors to make them exogenous to the fixed effects instead of transforming the regressors. Especially for small $\mathrm{T}$ and large $\mathrm{N}$ in an unbalanced panel setting, the Arellano and Bond (1991) method produces biased estimates. As our dataset covers a short period of time, contains many banks and is unbalanced, we estimate equations (6) and (7) by the system GMM approach suggested by Blundell and Bond (1998), using Roodman’s (2006) two-step system procedure. 


\section{DATA DESCRIPTION AND ANALYSIS}

The banking data for our analysis come from Bureau Van Dijk’s Bankscope database (December 2008) version. The data refer to 1997-2007 and cover commercial banks operating in more than 65 countries (29 OECD countries and 36 emerging market countries). Table A1 in the appendix provides the number of banks for each of the countries in our sample. To avoid double counting of banks, we include only banks with consolidated statements. Moreover, to keep the sample homogeneous we only consider commercial banks. We also deliberately exclude banks with a negative equity to asset ratio. After accounting for these changes, our final sample includes more than 3,900 observations for more than 1,500 banks.

We use bank assets as a proxy for bank size and return on average equity as a proxy for bank profitability. We include three bank-specific control variables. ${ }^{2}$ They account for the capital structure of the bank (i.e., equity/assets ratio), managerial efficiency of the banks (i.e., overhead costs to net income ratio) and stability of bank earnings (i.e., recurring earning power). The first control variable measures the portion of assets financed by equity. The higher this ratio, the higher the capital adequacy of the bank concerned will be. The second control variable measures the overhead costs to net income. If a bank has higher overhead costs as a ratio of net income, its profitability declines. The third control variable measures recurring earning power as a proxy of stability of earnings. ${ }^{3}$ As such, the recurring earning power reflects net income from the core business of the bank. Additionally, to incorporate macroeconomic conditions and the structure of the financial sector, we include real GDP growth, inflation, and bank concentration. ${ }^{4}$ Table 1 provides definitions of the dependent and explanatory variables and their sources.

\footnotetext{
${ }^{2}$ The bank-specific control variables are similar to those used by Goddard et al. (2004b) except for two major differences. First, we use overhead costs to income of banks and recurring earnings power as two additional variables. These variables incorporate managerial efficiency and earnings stability in the analysis. Furthermore, two variables used by Goddard et al. (2004b), namely off-balance sheet business of the bank and liquidity, are not used in our model for two reasons. In the first place, both of these variables appeared insignificant for commercial banks in the model of Goddard et al. (2004b). In the second place, the availability of data is limited and inclusion would significantly reduce the number of observations.

${ }^{3}$ This variable is very different from our dependent variable: the correlation of both variables is only 0.37 .

${ }^{4}$ Different from Goddard et al. (2004b), we include inflation in the model, as we want to control for the effect of an increasing or decreasing price level on bank assets and profitability.
} 


\begin{tabular}{|c|c|c|}
\hline \multicolumn{3}{|c|}{$\begin{array}{l}\text { TABLE } 1 \\
\text { VARIABLES: DEFINITIONS AND SOURCES } \\
\end{array}$} \\
\hline Variable: & Definition: & Source: \\
\hline Assets & Bank Assets (in US\$ 10000) & Bankscope \\
\hline Equity & Bank Equity (in US\$ 10000) & Bankscope \\
\hline Asset Growth & $\log \left(\operatorname{Assets}_{t}\right)-\log \left(\right.$ Assets $\left._{t-1}\right)$ & Bankscope \\
\hline Return on Assets & Returns as a ratio of bank assets & Bankscope \\
\hline Return on Equity & Returns as a ratio of bank equity & Bankscope \\
\hline Overhead Costs/Net Income & $\begin{array}{l}\text { The ratio of overhead bank costs to net income ratio. } \\
\text { Overhead refers to expenses that are necessary to the } \\
\text { continued functioning, but do not directly generate } \\
\text { profits. }\end{array}$ & Bankscope \\
\hline Recurring Earning Power & $\begin{array}{l}\text { This is an adjusted ratio of stable net income to assets } \\
\text { and excludes non-stable earnings and taxes from net } \\
\text { income before the calculation of the ratio. }\end{array}$ & Bankscope \\
\hline Equity/Assets & $\begin{array}{l}\text { As equity is a cushion against asset malfunction, this } \\
\text { ratio measures the amount of protection afforded to } \\
\text { the bank by the equity they invested in it. The higher } \\
\text { this figure the more protection there is. }\end{array}$ & Bankscope \\
\hline Real GDP Growth & $\log \left(r\right.$ e $\left.a l G D P_{t}\right)-\log \left(r\right.$ e $\left.a l G D P_{t-1}\right)$ & World Bank World Development Indicators \\
\hline Inflation & $\begin{array}{l}\text { Change in Consumer Price Index. To adjust for } \\
\text { extreme movements, we modify the inflation rate (P) } \\
\text { as } \frac{P / 100}{1+(P / 100)}\end{array}$ & World Bank World Development Indicators \\
\hline Concentration & Fraction of Assets held by three largest banks & Beck et al. (2000) - Financial Structures Database \\
\hline
\end{tabular}




\begin{tabular}{|l|c|c|c|c|c|}
\hline $\begin{array}{l}\text { TABLE 2 } \\
\text { SuMMARY STATISTICS }\end{array}$ & Mean & $\begin{array}{c}\text { Standard } \\
\text { Deviation }\end{array}$ & Minimum & Maximum & Observations \\
\hline Variable: & 25.70 & 280.84 & 0.00 & 9730.00 & 7,783 \\
\hline Assets (in US\$ 10000) & 2.79 & 35.87 & 0.00 & 1250.00 & 7,765 \\
\hline Equity (in US\$ 10000) & 0.17 & 0.47 & -6.92 & 4.66 & 5,759 \\
\hline Asset Growth & 1.11 & 4.76 & -111.13 & 73.17 & 7,720 \\
\hline Return on Assets & 9.85 & 30.87 & -927.38 & 615.39 & 7,699 \\
\hline Return on Equity & 3.74 & 30.69 & -1668.39 & 702.54 & 7,526 \\
\hline Overhead Costs/Income & 2.13 & 4.93 & -81.09 & 96.30 & 7,713 \\
\hline Recurring Earning Power & 15.68 & 17.96 & 0.00 & 100.00 & 7,765 \\
\hline Equity/Assets & 0.03 & 0.02 & -0.14 & 0.26 & 715 \\
\hline Real GDP Growth & 0.03 & 0.04 & -0.09 & 0.61 & 715 \\
\hline Inflation & 0.41 & 0.22 & 0.20 & 1.00 & 715 \\
\hline Concentration & & & & & \\
\hline
\end{tabular}


Table 2 provides the summary statistics of our data and Table A2 in the appendix provides the correlation matrix of the variables. The correlations between the explanatory variables are low suggesting that multicolinearity is not a problem.

Many of our data come from Bankscope. However, Bankscope has been criticized for being not sufficiently representative of the banking systems of the countries covered (see, for instance, Bhattacharya, 2003). To check whether our sample is sufficiently representative we compare our sample of banks in terms of return on assets and return on equity with the World Bank Financial Structure database of Beck et al. (2000). ${ }^{5}$ As Table A3 in the appendix shows, the averages in our sample are very similar to the overall banking sector statistics in the World Bank dataset. One possible reason for the small differences is that our sample is based on commercial banks only, whereas the World Bank sample also includes investment, co-operative, and micro-finance banks.

As we are using a large dataset of banking firms, it is useful to discuss some developments in bank size in the period under investigation. Bank size distribution as measured by assets is highly skewed towards the right, i.e., there are many small banks and only a few large banks. This pattern is so clear that a normal plot of bank size is not informative (see also Janicki and Prescott, 2006). Therefore, we show the log of bank size for all OECD and non-OECD banks in our sample over the period 1997-2007 in Figure 1 and Figure 2, respectively. Additionally, we present year-wise skewness, kurtosis and Jarque-Bera test statistics for both OECD and non-OECD countries in Table A4 in the appendix. Our findings suggest that over the period 1997-2007, the size distribution of banks in the OECD countries converged to the lognormal distribution but this does not hold true for non-OECD countries. In OECD countries the leptokurtosis was reduced, but in non-OECD countries logarithmic bank sizes are still peaked, although there is a trend towards the reduction of kurtosis in these countries too.

\footnotetext{
${ }^{5}$ These are the only two variables that are common in both datasets.
} 


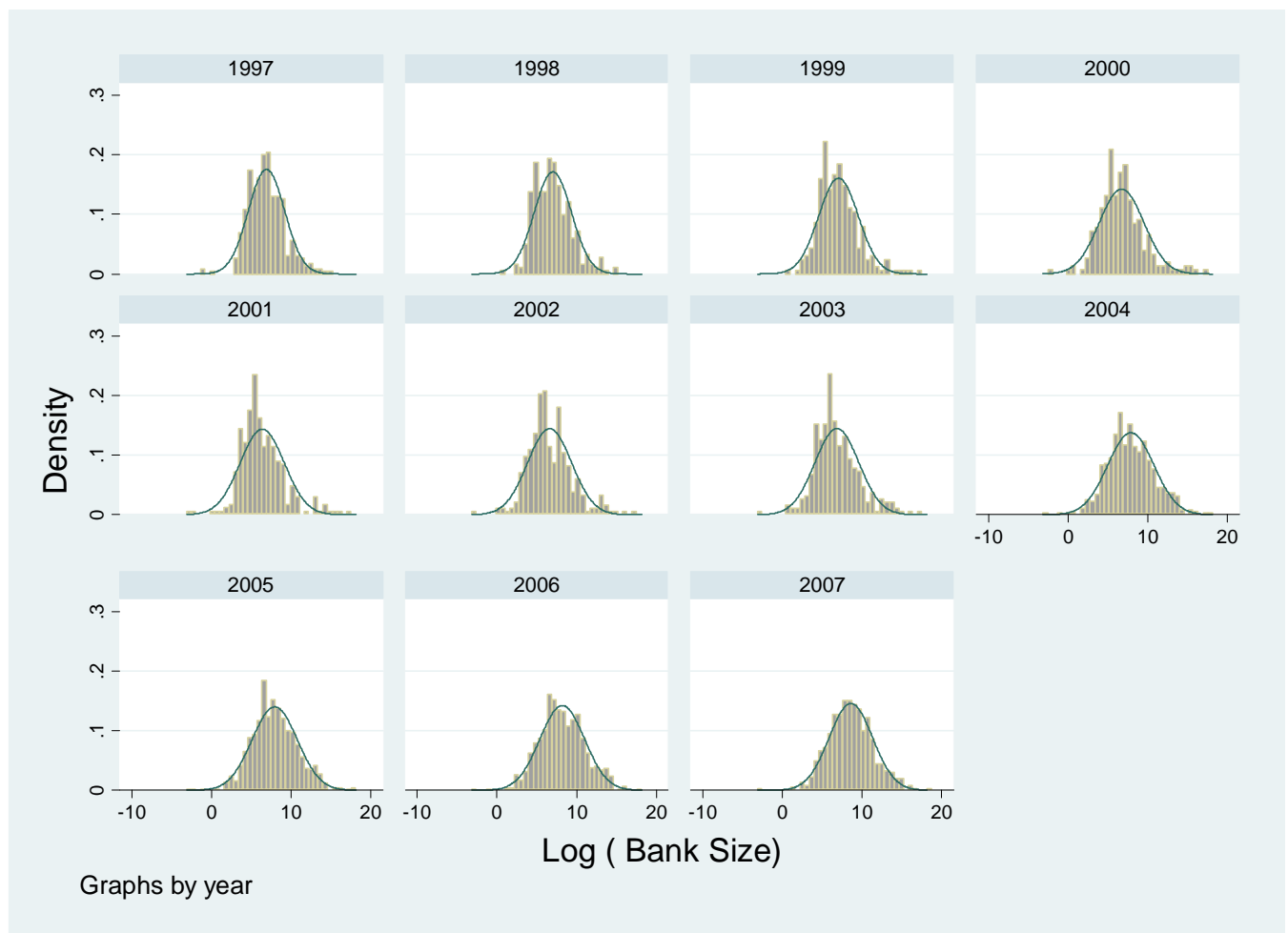

Fig. 1 Density of the log of bank sizes in OECD countries

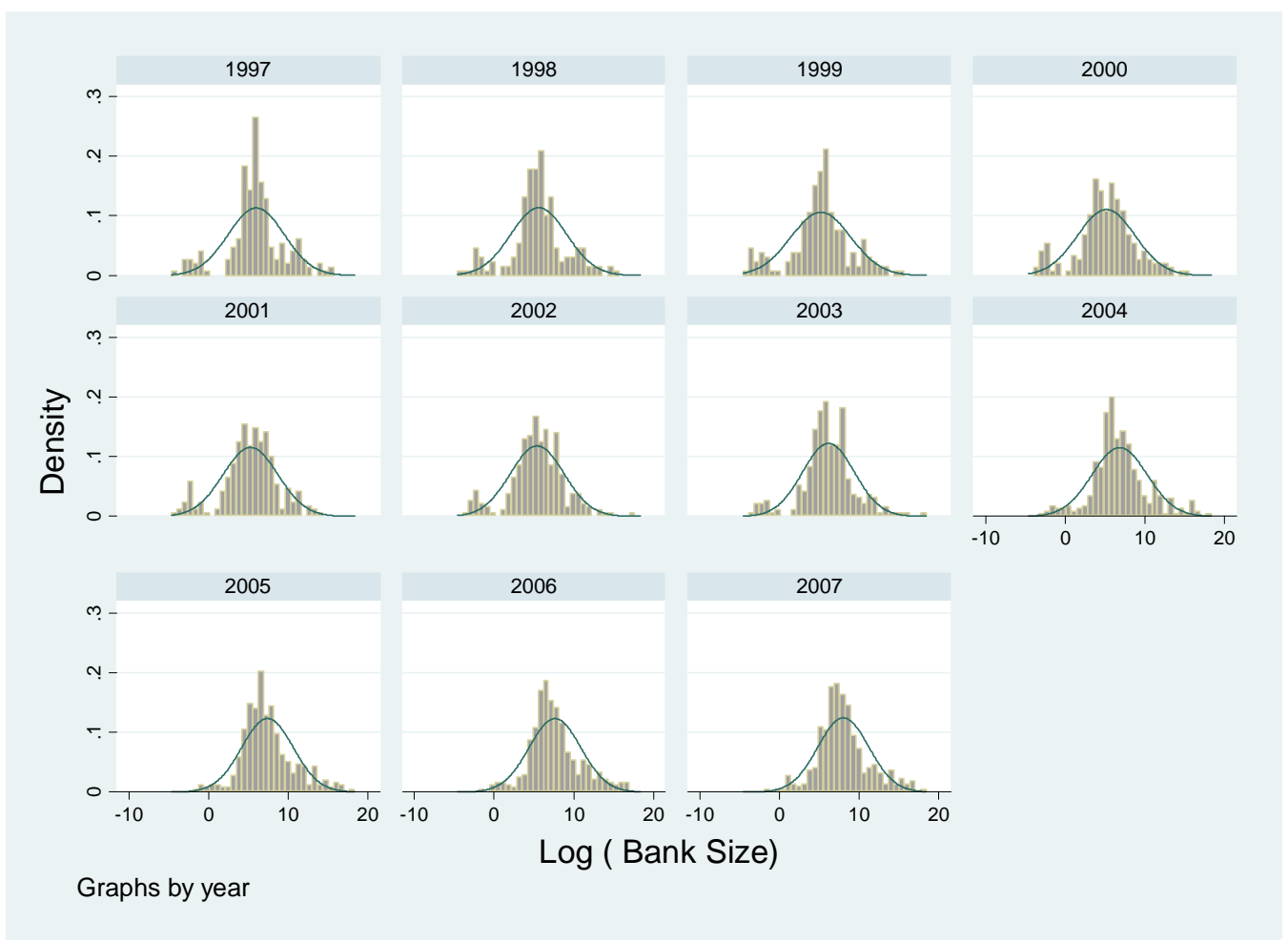

Fig. 2 Density of the log of bank size for non-OECD countries 


\section{ESTIMATION RESULTS FOR THE FULL SAMPLE}

The estimation results for the full sample are presented in columns (1)-(3) of Table 3 and Table 4 for bank growth and bank profitability, respectively. In model 1 in Table 3 bank growth is regressed on lagged growth and lagged bank size. In model 2, lagged profitability is taken up as an explanatory variable, whereas in model 3 all explanatory variables are included. The Wald Chi-squared test is significant at the 1 percent level of significance and the Hansen test of over-identifying restriction appears insignificant. The null hypothesis of the Hansen test is that the population moment conditions are correct and failure to reject the null hypothesis indicates the validity and exogeneity of the instruments. ${ }^{6}$ For the consistent estimation of the models, a crucial condition is that the error terms are serially uncorrelated. More specifically, $\Delta \xi_{i t}$ should be uncorrelated ${ }^{7}$ with $\Delta \xi_{i, t-k}$ for $k \geq 2$ and this can be examined by the Arellano-Bond test for first and second difference autoregressive processes. The test for the first difference autoregressive process appears significant, whereas it is insignificant for the second difference indicating that error terms are serially uncorrelated in our models.

Columns (1)-(3) of Table 4 provide results for the bank profitability models corresponding to equation (7) for the full sample. In model 1, profitability of a bank is regressed on lagged profitability only. In model 2, bank size is taken up as an explanatory variable, and in model 3 all explanatory variables are included. The Wald Chi-squared test is again significant at the 1 percent level of significance and the Hansen test of overidentifying restriction appears insignificant, suggesting the validity and exogeneity of the instruments. Similar to the models for bank growth, the Arellano-Bond test for the first difference autoregressive process appears to be significant and the second difference appears to be insignificant.

\footnotetext{
${ }^{6}$ It may be important to mention here that in some models, the Sargan test for the instrument invalidity appears significant. However, as pointed out by Roodman (2006), the Sargan test can be inconsistent, because of the non-sphericity of errors and in that case the Hansen statistic from two-step estimate, which we report in our tables, is a better test.

${ }^{7}$ If errors are serially uncorrelated $\Delta \xi_{i, t}$ are correlated with $\Delta \xi_{i, t-1}$ but not with $\Delta \xi_{i, t-k}$ for $k \geq 2$.
} 


\section{Hypothesis 1: Bank growth (profitability) is independent of bank size}

To test this hypothesis, we examine the coefficient of logarithmic bank size ( $\beta$-1). For the bank growth equation, the models 1-3 in Table 3 show that this coefficient has a negative sign, which implies that large banks grow slower than small banks. This finding is consistent with our observation that bank sizes converge to the lognormal distribution but contradicts the findings of Goddard et al. (2004b) who report a positive impact of bank size on bank growth. For the profitability equation results in Table 4, models 2-3 reveal that bank size does not affect profitability. Therefore, we cannot reject the hypothesis that $\beta=0$. This finding suggests that bank profitability is not affected by bank size. This result is very similar to the findings of Goddard et al. (2004a) and Athanasoglu et al. (2005).

\section{Hypothesis 2: Bank growth (profitability) variability is independent of bank size}

To examine the effect of bank size on variability of bank growth and profitability, we plot the residuals of our models 1-3 (as reported in columns (1)-(3) of Tables 3 and 4 for the full sample) in Figures 3 and 4 for growth and profitability, respectively. The residuals from the bank growth models 1 and 2 do not suggest any systematic variation in the residuals. In model 3, the test for the normality of the residuals shows no significant trend as well. So hypothesis 2 is not rejected for bank growth. On the other hand, in the bank profitability models, we find that variation in profitability is slightly higher for smaller banks compared to large banks.

\section{Hypothesis 3: Bank growth (profitability) is not persistent}

In Table 3, where we present the results for bank growth, lagged bank growth appears insignificant in all three formulations of the model, implying no persistence in bank growth. So hypothesis 3 can be rejected for bank growth. On the other hand, lagged bank profitability appears to be significant in all three models in Table 4, indicating persistence of bank profitability. This result is similar to the findings of Goddard et al. (2004a; 2004b). Our results imply that lagged bank growth has no predictive power for current bank growth. 
Hypothesis 4: Bank profitability (growth) has no effect on bank growth (profitability) In some specifications as reported in Table 3, bank profitability predicts the bank's growth but this result is not robust as in the full model significance of profitability is rejected. However, in the model for bank profitability the coefficient of lagged growth is significant at the 5 percent level, suggesting that banks growing faster in the previous period tend to have higher profitability in the current period. 


\begin{tabular}{|c|c|c|c|c|c|c|c|c|c|c|}
\hline \multicolumn{11}{|l|}{$\begin{array}{l}\text { TABLE } 3 \\
\text { DYNAMIC PANEL ESTIMATION RESULT }\end{array}$} \\
\hline & & \multicolumn{3}{|c|}{ Full sample } & \multicolumn{3}{|c|}{ OECD Countries } & \multicolumn{3}{|c|}{ Non-OECD Countries } \\
\hline & & $(1)$ & \begin{tabular}{|l|}
$(2)$ \\
\end{tabular} & $(3)$ & $(4)$ & \begin{tabular}{|l|} 
(5) \\
\end{tabular} & \begin{tabular}{|l|}
$(6)$ \\
\end{tabular} & (7) & (8) & (9) \\
\hline \multirow[t]{2}{*}{ Bank Growth (t-1) } & Coefficient & 0.33 & 0.009 & -0.015 & 0.143 & 0.23 & 0.012 & $0.817 * * *$ & 0.112 & $-0.187 *$ \\
\hline & Std. Error & 0.215 & 0.243 & 0.044 & 0.675 & 0.413 & 0.047 & 0.306 & 0.25 & 0.101 \\
\hline \multirow[t]{2}{*}{ Bank Size (t-1) } & Coefficient & $-0.095^{* * *}$ & $-0.058^{*}$ & $-0.515^{* *}$ & $-0.094 *$ & $-0.084 * * *$ & $-0.458 * * *$ & -0.054 & -0.049 & -0.203 \\
\hline & Std. Error & 0.027 & 0.032 & 0.202 & 0.056 & 0.024 & 0.11 & 0.048 & 0.034 & 0.148 \\
\hline & Std. Error & & 0.032 & 0.068 & & 0.041 & 0.054 & & 0.025 & 0.081 \\
\hline \multirow[t]{2}{*}{ Equity/Assets Ratio } & Coefficient & & & $-0.038^{* *}$ & & & $-0.042^{* * *}$ & & & $-0.028^{*}$ \\
\hline & Std. Error & & & 0.019 & & & 0.013 & & & 0.016 \\
\hline \multirow[t]{2}{*}{ Overhead Costs/Income } & Coefficient & & & -0.032 & & & 0 & & & $0.046 *$ \\
\hline & Std. Error & & & 0.029 & & & 0.008 & & & 0.023 \\
\hline \multirow[t]{2}{*}{ Real GDP Growth } & Coefficient & & & 2.381 & & & 9.428 & & & 1.344 \\
\hline & Std. Error & & & 2.248 & & & 6.765 & & & 1.518 \\
\hline \multirow[t]{2}{*}{ Inflation } & Coefficient & & & 0.251 & & & -8.087 & & & 1.56 \\
\hline & Std. Error & & & 2.477 & & & 12.261 & & & 2.476 \\
\hline \multirow[t]{2}{*}{ Concentration } & Coefficient & & & -0.306 & & & -0.482 & & & 0.576 \\
\hline & Std. Error & & & 0.771 & & & 0.751 & & & 0.717 \\
\hline Number of Observations & & 3972 & 3484 & 1879 & 2390 & 2054 & 1014 & 1582 & 1430 & 865 \\
\hline Number of Banks & & 1569 & 1451 & 838 & 989 & 908 & 449 & 580 & 543 & 389 \\
\hline Number of Instruments & & 13 & 21 & 19 & 12 & 18 & 19 & 13 & 21 & 19 \\
\hline $\mathrm{AB}$ test for $\mathrm{AR}(1)$ & & -2.095 & -1.664 & -1.201 & -0.707 & -1.471 & -1.532 & -2.57 & -1.556 & -1.417 \\
\hline Prob (AB test for AR(1)) & & 0.036 & 0.096 & 0.23 & 0.479 & 0.141 & 0.126 & 0.01 & 0.12 & 0.156 \\
\hline AB test for AR(2) & & 0.996 & 0.202 & 0.423 & 0.181 & 0.583 & -1.064 & 0.287 & 0.901 & 1.069 \\
\hline Prob (AB test for AR(2)) & & 0.319 & 0.84 & 0.672 & 0.856 & 0.56 & 0.287 & 0.774 & 0.368 & 0.285 \\
\hline Hansen Test of Over identifying Restrictions & & 14.345 & 20.568 & 9.592 & 8.301 & 12.151 & 5.745 & 11.85 & 19.504 & 3.674 \\
\hline Prob (Hansen Test of Over identifying Restrictions) & & 0.214 & 0.302 & 0.477 & 0.599 & 0.668 & 0.836 & 0.375 & 0.361 & 0.961 \\
\hline Wald Chi2 Test & & $107.295^{* * *}$ & $141.082^{* * *}$ & $35.387 * * *$ & $93.687 * * *$ & $95.410^{* * * *}$ & $98.976^{* * *}$ & $121.063 * * *$ & $119.207^{* * *}$ & $32.370^{* * *}$ \\
\hline
\end{tabular}




\begin{tabular}{|c|c|c|c|c|c|c|c|c|c|c|}
\hline \multicolumn{11}{|c|}{$\begin{array}{l}\text { TABLE } 4 \\
\text { DYNAMIC PANEL ESTIMATION RESULTS (DEPENDENT VARIABLE IS BANK PROFITABIL }\end{array}$} \\
\hline & & \multicolumn{3}{|c|}{ Full sample } & \multicolumn{3}{|c|}{ OECD Countries } & \multicolumn{3}{|c|}{ Non-OECD Countries } \\
\hline & & $(1)$ & (2) & (3) & (4) & (5) & (6) & $(7)$ & (8) & (9) \\
\hline & & Model 1 & Model 2 & Model 3 & Model 1 & Model 2 & Model 3 & Model 1 & Model 2 & Model 3 \\
\hline \multirow[t]{2}{*}{ Return on Equity (t-1) } & Coefficient & $0.916^{* * *}$ & $0.959^{* * *}$ & $0.655^{* * *}$ & $0.943^{* * *}$ & $0.977 * * *$ & $0.591^{* * *}$ & $0.850^{* * *}$ & $0.908^{* * *}$ & $0.926^{* * *}$ \\
\hline & Std. Error & 0.029 & 0.035 & 0.172 & 0.034 & 0.075 & 0.078 & 0.058 & 0.078 & 0.181 \\
\hline \multirow[t]{2}{*}{ Bank Size (t-1) } & Coefficient & & -0.031 & 0.048 & & -0.024 & -0.094 & & -0.109 & 0.014 \\
\hline & Std. Error & & 0.053 & 0.038 & & 0.105 & 0.107 & & 0.103 & 0.034 \\
\hline \multirow[t]{2}{*}{ Bank Growth (t-1) } & Coefficient & & & $0.926 * *$ & & & $0.828 *$ & & & 0.11 \\
\hline & Std. Error & & & 0.445 & & & 0.485 & & & 0.332 \\
\hline \multirow{2}{*}{ Equity/Assets Ratio } & Coefficient & & & -0.001 & & & -0.007 & & & $-0.008^{* *}$ \\
\hline & Std. Error & & & 0.003 & & & 0.009 & & & 0.003 \\
\hline \multirow{2}{*}{ Overhead Costs/Income } & Coefficient & & & $-0.022 * *$ & & & $-0.031 * * *$ & & & $-0.014 *$ \\
\hline & Std. Error & & & 0.009 & & & 0.006 & & & 0.008 \\
\hline \multirow{2}{*}{ Real GDP Growth } & Coefficient & & & 1.385 & & & $8.995 * * *$ & & & -0.922 \\
\hline & Std. Error & & & 1.72 & & & 2.559 & & & 1.643 \\
\hline \multirow{2}{*}{ Inflation } & Coefficient & & & 2.86 & & & 2.546 & & & -0.435 \\
\hline & Std. Error & & & 2.169 & & & 2.407 & & & 1.086 \\
\hline \multirow[t]{2}{*}{ Recurring Earning Power } & Coefficient & & & $0.061 * * *$ & & & $0.045^{* * *}$ & & & $0.068 * * *$ \\
\hline & Std. Error & & & 0.011 & & & 0.006 & & & 0.013 \\
\hline \multirow[t]{2}{*}{ Concentration } & Coefficient & & & $0.962 * * *$ & & & $0.660^{* *}$ & & & 0.431 \\
\hline & Std. Error & & & 0.357 & & & 0.277 & & & 0.585 \\
\hline Number of Observations & & 4625 & 4625 & 1763 & 2766 & 2766 & 945 & 1859 & 1859 & 818 \\
\hline Number of Banks & & 1522 & 1522 & 795 & 953 & 953 & 425 & 569 & 569 & 370 \\
\hline Number of Instruments & & 8 & 16 & 21 & 8 & 14 & 20 & 8 & 16 & 21 \\
\hline $\mathrm{AB}$ test for $\mathrm{AR}(1)$ & & -7.803 & -7.864 & -4 & -5.997 & -5.734 & -2.775 & -5.092 & -4.97 & -3.027 \\
\hline Prob (AB test for AR(1)) & & 0 & 0 & 0 & 0 & 0 & 0.006 & 0 & 0 & 0.002 \\
\hline $\mathrm{AB}$ test for $\mathrm{AR}(2)$ & & 0.994 & 0.983 & -1.176 & 1.256 & 1.249 & 0.239 & 0.176 & 0.163 & -0.743 \\
\hline Prob (AB test for AR(2)) & & 0.32 & 0.326 & 0.24 & 0.209 & 0.212 & 0.811 & 0.86 & 0.871 & 0.457 \\
\hline Hansen Test of Over identifying Restrictions & & 1.94 & 17.445 & 17.348 & 6.11 & 14.139 & 5.103 & 3.379 & 20.989 & 14.296 \\
\hline Prob (Hansen Test of Over identifying Restrictions) & & 0.963 & 0.233 & 0.137 & 0.527 & 0.292 & 0.926 & 0.848 & 0.102 & 0.282 \\
\hline Wald Chi2 Test & 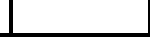 & $966.360 * * *$ & $3180.503^{* * *}$ & $16647.399 * * *$ & $787.501^{* * *}$ & $3906.085^{* * *}$ & $5719.356^{* * *}$ & $216.047^{* * *}$ & $1868.898^{* * *}$ & $7750.279 * * *$ \\
\hline
\end{tabular}



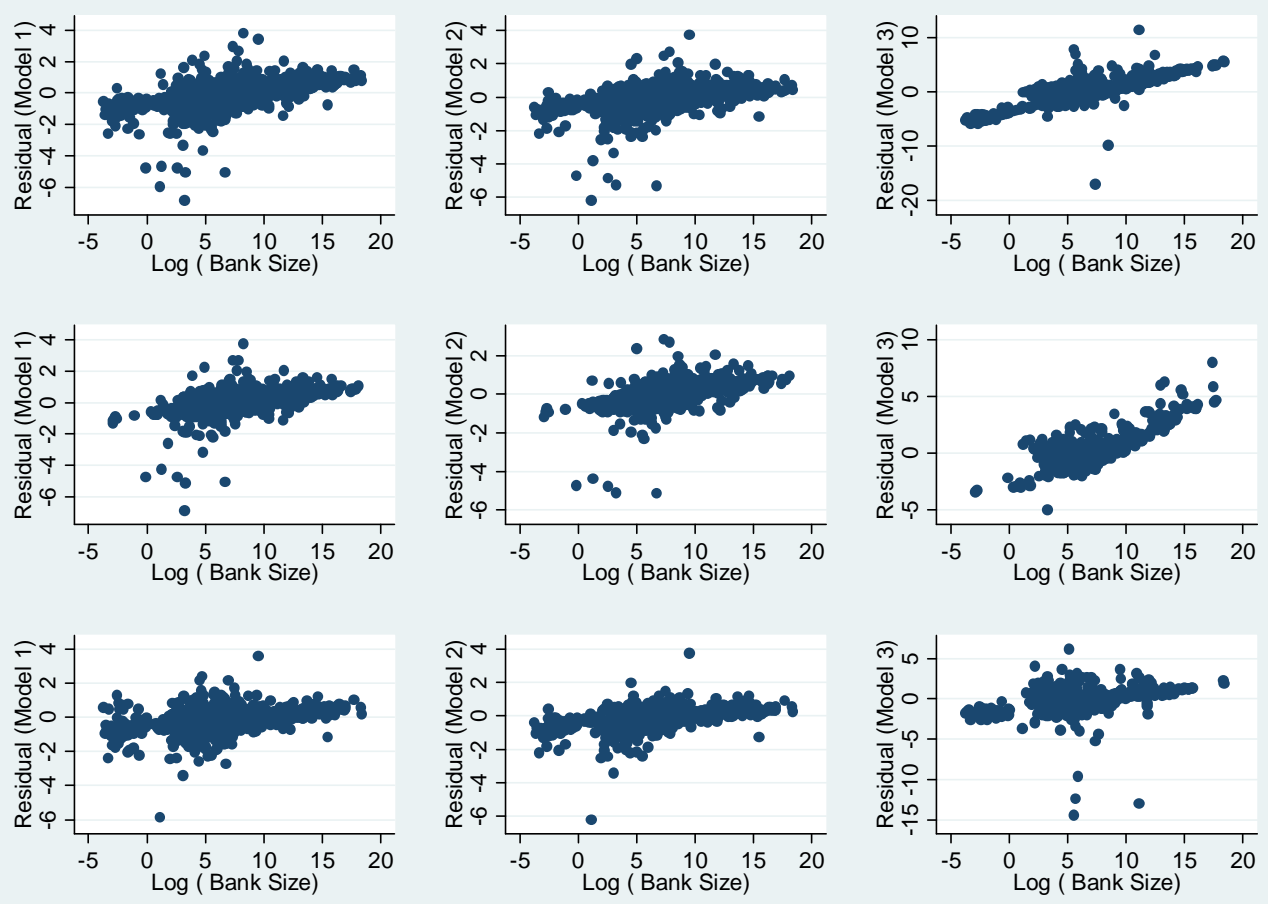

This figure plots the residuals form our model 1-3 against logarithmic bank size corresponding to results reported in Table 3. The upper row draws the residuals of model 1-3 against logarithmic bank size for all countries as reported in columns (1)-(3) of Table 3. The row in the middle plots the residuals of models 1-3 estimated for the OECD countries only as reported in columns (4)-(6) in Table 3. The bottom row presents the graphs corresponding to columns (7)-(9) of Table 3 where we estimate our models 1-3 for non-OECD countries only.

Fig. 3 Residual Plots of Growth Regressions against Bank Size 

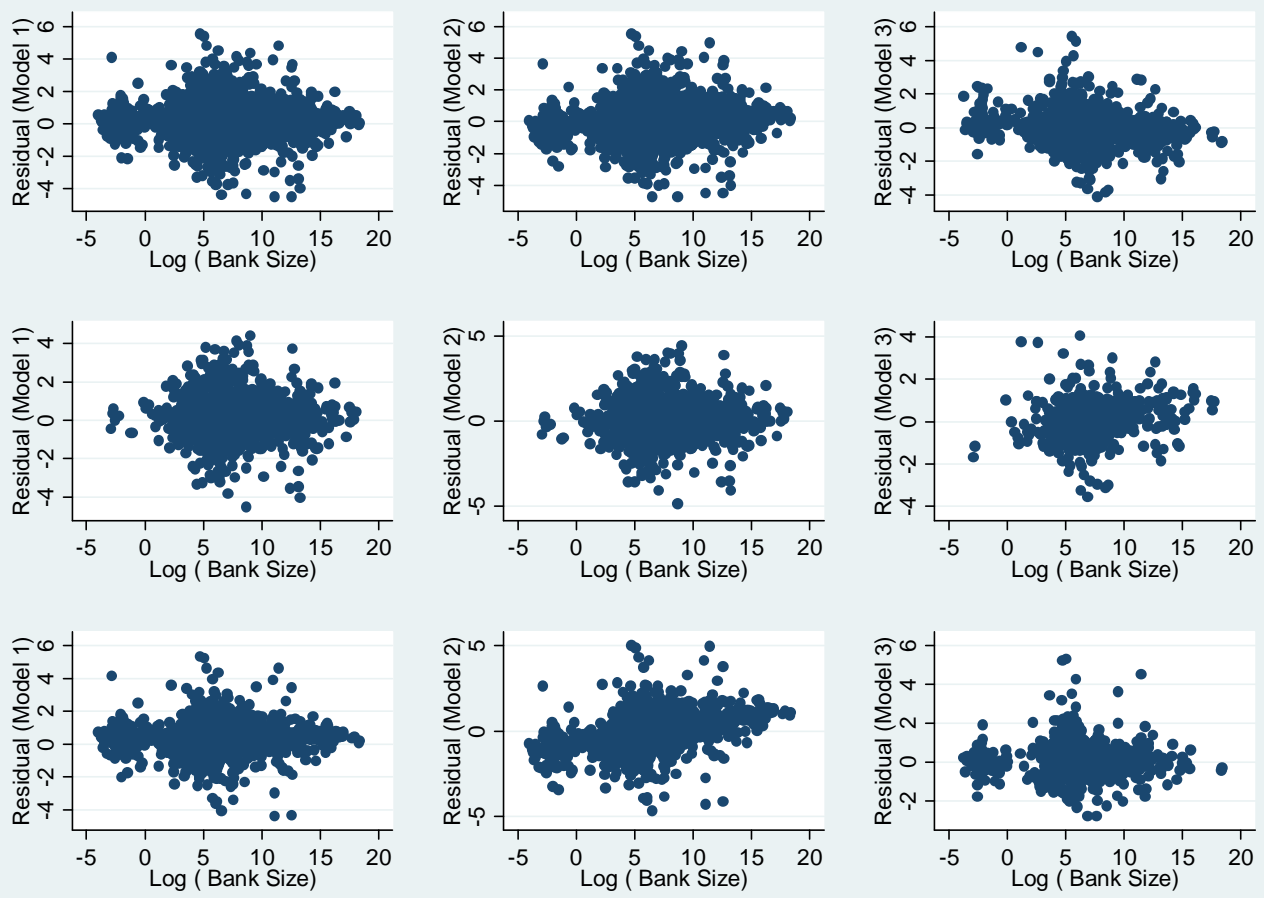

This figure plots the residuals form our model 1-3 against logarithmic bank size corresponding to results reported in Table 4. The upper row draws the residuals of model 1-3 against logarithmic bank size for all countries as reported in columns (1)-(3) of Table 4 . The row in the middle row the residuals of models 1-3 estimated for OECD countries only as reported in columns (4)-(6) in Table 4. The bottom row presents the graphs corresponding to columns (7)-(9) of Table 4 where we estimate our models 1-3 for non-OECD countries only.

Fig. 4 Residual Plots of Profitability Regressions against Bank Size 
We also examine the effect of other control variables, like equity to assets ratio, overhead costs to income ratio, real GDP growth, inflation, recurring earning power, and concentration, on bank growth and profitability. For the growth models, as reported in Table 3, our results indicate that a higher equity to assets ratio has a negative impact on bank growth. This result is significant at the 5 percent level. Other variables do not appear to be significant. Regarding bank profitability, we find that an increase in the overhead costs to income ratio reduces bank profitability. However, an increase in recurring earning power increases bank profitability and increased concentration also results in higher profitability. A possible explanation for the positive relationship between concentration and profitability is that more concentration may imply more market power, which, in turn, may increase profit margins.

\section{OECD VS. NON-OECD COUNTRIES}

As shown in the data analysis section, the structure of the banking system of OECD countries is quite different from that of non-OECD countries. Therefore, we think it is interesting to estimate models 1-3 for both groups of countries. Our samples for OECD and non-OECD countries contain more than 900 and 500 banks, respectively. However, because of the unavailability of data for some control variables, the number of banks drops in model 3 (with all control variables). Table 3 presents the results for bank growth for OECD countries in columns (4)-(6) and for non-OECD countries in columns (7)-(9). For both samples, the models are significant at 1 percent level of significance as shown by the Wald chi-square test. Moreover, the Hansen test of over-identifying restrictions always appears insignificant implying that the null hypothesis of correct population moment conditions is not rejected. This result points at the validity and exogeneity of the instruments. The Arellano-Bond test for the first difference autoregressive process appears to be significant and the test for the second difference autoregressive process is insignificant implying that our modeling techniques are suitable.

The main difference between the two subsamples is that bank size is not significant in all models for bank growth for non-OECD countries. In contrast, for OECD countries the coefficient of bank size comes up with a negative sign and is significantly 
different from zero. Similarly, the equity to assets ratio is significant at the 1 percent level for OECD countries, whereas it is only significant at the 10 percent level for non-OECD countries. Recall that in the total sample, this variable was significant at the 5 percent level.

Table 4 presents the results for growth in profitability for OECD and non-OECD countries. The results for OECD countries are presented in columns (4)-(6) and for nonOECD countries in columns (7)-(9). The significance of the Wald-Chi-square tests, at 1 percent level of significance, implies that all models are significant for both OECD and non-OECD countries. Similarly, the insignificance of the Hansen test of over-identifying restriction implies that the instruments are exogenous. The Arellano-Bond test results for differences in first-order and second-order autoregressive process indicate no autoregressive process at second stage.

The effect of lagged profitability remains significant for both OECD and nonOECD countries, indicating persistence of bank profitability. Similarly, the effect of bank size appears insignificant for both OECD and non-OECD countries, which implies that bank size does not affect growth of profitability. However, lagged bank growth does not have a significant impact on bank profitability for banks located in non-OECD countries. A possible explanation for this result can be a weakness in the banking firms, which cannot channel growth into profitability.

Most results concerning the control variables in the models for the subsamples are similar to our results for the overall sample. However, one interesting difference is that concentration does not result in higher profitability in non-OECD countries. This could reflect the presence of a few large unprofitable banks. As pointed out by others (see, e.g., Bonin et al., 2005), some non-OECD countries have large state-run banks with low profitability. A second interesting difference is that real GDP growth appears significant for banks in OECD countries with the expected positive sign but is insignificant for banks located in non-OECD countries. The insignificance of GDP growth for bank profitability has been documented before (see, e.g., Demirgüç-Kunt et al., 1999). In line with our findings, Bikker and Hu (2003) report a positive impact of GDP growth on bank profitability of 26 industrial countries. 


\section{CONCLUSIONS}

We examine Gibrat's 'Law of Proportionate Effect' for more than 1500 banks from 65 OECD and non-OECD countries. Following Goddard et al. (2004a, 2004b), we also analyze the linkages between bank growth and profitability. Our analysis shows that concentration in the banking sector has decreased in both OECD and non-OECD countries, but non-OECD countries still have a more peaked distribution of banks. We model bank size and profitability growth using the Blundell and Bond (1998) two-step GMM approach. Our findings suggest that (i) bank growth is not persistent, (ii) bank profitability is persistent, (iii) bank size does not affect bank growth for banks located in non-OECD countries but in OECD countries large banks grow at lower speed (iv) variability in bank growth is not influenced by bank size, and (v) smaller banks face more variation in profitability. Overall these results imply that Gibrat's 'Law of Proportionate Effect' does not hold for the banking industry. Additionally, we show that banks with lower managerial efficiency observe lower growth in their profitability. Moreover, banks in more concentrated banking sectors tend to have higher profitability. 


\section{LITERATURE CITED}

Arellano, Manuel, and Stephen Bond. (1991) "Some Tests of Specification for Panel Data: Monte Carlo Evidence and an Application to Employment Equations.” Review of Economic Studies, 58:2, 277-97.

Arellano, Manuel, and Olympia Bover. (1995) "Another Look at the Instrumental Variable Estimation of Error-components Models." Journal of Econometrics, 68:1, 2951.

Athanasoglou, Panayiotis P., Sophocles N. Brissimis, and Matthaios D. Delis. (2005) "Bank-Specific, Industry-Specific and Macroeconomic Determinants of Bank Profitability.” Working Papers 25, Bank of Greece.

Beck, Thorsten, Asli Demirgüç-Kunt, and Ross Levine. (2000) "A New Database on Financial Development and Structure.” World Bank Economic Review, 14, 597-605.

Benito, Enrique. (2008) "Size, Growth and Bank Dynamics.” Banco de España Working Papers 0801, Banco de España.

Berger, Allen N. (1995) "The Profit-Structure in Banking - Tests of Market Power and Efficient Structure Hypotheses.” Journal of Money, Credit, and Banking, 27:2, 404-431.

Berger, Allen N., Nathan H. Miller, Mitchell A. Peterson, Raghuram G. Rajan, and Jeremy C. Stein. (2005) "Does Function Follow Organizational Form? Evidence from the Lending Practices of Large and Small Banks.” Journal of Financial Economics, 76, 237269

Bikker Jacob A., and Haixia Hu. (2003) "Cyclical Patterns in Profits, Provisioning and Lending of Banks.” DNB Staff Reports 86, Netherlands Central Bank.

Bhattacharya, Kaushik. (2003) "How Good is the BankScope Database? A CrossValidation Exercise With Correction Factors for Market Concentration Measures.”. BIS Working Paper No 133, Bank for International Settlements, Ch-4002, Basel, Switzerland.

Blundell, Richard, and Stephen Bond. (1998) "Initial Conditions and Moment Restrictions in Dynamic Panel Data Models.” Journal of Econometrics, 87:1, 115-143.

Bonin John P., Iftekhar Hasan, and Paul Wachtel. (2005) "Bank Performance, Efficiency and Ownership in Transition Countries.” Journal of Banking and Finance, 29:1, 31-53.

Breitung, Jorg, and Wolfgang Meyer. (1994) "Testing for Unit Roots in Panel Data: Are Wages on Different Bargaining Levels Cointegrated?” Applied Economics, 26:4, 353-61.

Demirgüç-Kunt, Asli, and Harry Huizinga. (1999) "Determinants of Commercial Bank Interest Margins and Profitability: Some International Evidence,” World Bank Economic Review, 13:2, 379-408.

Gibrat, Robert. (1931). Les Inégalités Economiques. Paris: Recueil Sirey. 
Goddard, John, Phil Molyneux, and John O.S. Wilson. (2004a) "The Profitability of European banks: a cross-sectional and dynamic panel analysis.” Manchester School, 72: 3, 363-381.

Goddard, John, Phil Molyneux, and John O.S. Wilson. (2004b) "Dynamics of Growth and Profitability in Banking.” Journal of Money, Credit, and Banking, 36:6, 1069-90.

Hameeteman, Daphne, and Bert Scholtens. (2000) "Size, Growth, and Variance among the World's Largest Non-merged Banks." International Journal of the Economics of Business, 7, 313-323.

Hannan, Timothy H. (1991) "Foundations of the Structure-Conduct-Performance Paradigm in Banking.” Journal of Money, Credit, and Banking, 23:1, 68-84.

Janicki, Hubert P., and Edward S. Prescott. (2006) "Changes in the Size Distribution of U.S. banks: 1960-2005.” Economic Quarterly, Federal Reserve Bank of Richmond, Fall, 291-316.

Mason, Edward S. (1939) "Price and Production Policies of Large-Scale Enterprise." American Economic Review, 29, 61-74.

Roodman David. (2006). "How to Do xtabond2: An Introduction to "Difference" and "System" GMM in Stata.” Working Papers 103, Center for Global Development.

Smirlock, M. (1985) "Evidence on the (non) Relationship between Concentration and Profitability in Banking.” Journal of Money, Credit, and Banking, 17:1, 69-83.

Stein, Jermey C. (2002) "Information Production and Capital Allocation: Decentralized versus Hierarchical Firms.” Journal of Finance, 57:5, 1891-1921.

Stever, Ryan. (2007) "Bank Size, Credit and the Sources of Bank Market Risk.” BIS Working Paper No 238, Bank for International Settlements, Ch-4002, Basel, Switzerland

Tschoegl, Adrian E. (1983) "Size, Growth, and Transnationality among the World's Largest Banks.” Journal of Business, 56:2, 187-201.

Vasilis Sarafidis, Yamagata Takashi, and Donald Robertson. (2009) "A Test of Cross Section Dependence for a Linear Dynamic Panel Model with Regressors.” Journal of Econometrics, 148:2, 149-161. 
APPENDIX

\begin{tabular}{|c|c|c|c|}
\hline \multicolumn{4}{|c|}{$\begin{array}{l}\text { TABLE A1 } \\
\text { COUNTRY-WISE DISTRIBUTION OF BANKS IN SAMPLE } \\
\end{array}$} \\
\hline Country & Banks & Country & Banks \\
\hline ARGENTINA & 27 & KOREA (SOUTH) & 3 \\
\hline AUSTRALIA & 19 & KUWAIT & 1 \\
\hline AUSTRIA & 51 & LUXEMBOURG & 31 \\
\hline BANGLADESH & 6 & MALAYSIA & 20 \\
\hline BELGIUM & 19 & MALI & 2 \\
\hline BELIZE & 3 & MEXICO & 18 \\
\hline BRAZIL & 82 & MOROCCO & 8 \\
\hline BURUNDI & 1 & NETHERLANDS & 32 \\
\hline CANADA & 21 & NEW ZEALAND & 4 \\
\hline CHAD & 1 & NIGERIA & 37 \\
\hline CHILE & 10 & NORWAY & 9 \\
\hline CHINA (PEOPLE'S REPUBLIC) & 58 & OMAN & 3 \\
\hline COLOMBIA & 12 & PAKISTAN & 14 \\
\hline CROATIA & 22 & PANAMA & 52 \\
\hline CYPRUS & 5 & PHILIPPINES & 26 \\
\hline CZECH REPUBLIC & 8 & POLAND & 34 \\
\hline DENMARK & 24 & PORTUGAL & 18 \\
\hline EGYPT & 2 & QATAR & 1 \\
\hline ESTONIA & 2 & ROMANIA & 14 \\
\hline FINLAND & 6 & SINGAPORE & 8 \\
\hline FRANCE & 78 & SLOVAKIA & 9 \\
\hline GABON & 1 & SOUTH AFRICA & 24 \\
\hline GERMANY & 57 & SPAIN & 47 \\
\hline GHANA & 6 & SRI LANKA & 4 \\
\hline GREECE & 19 & SWEDEN & 17 \\
\hline HUNGARY & 11 & SWITZERLAND & 55 \\
\hline ICELAND & 4 & TURKEY & 14 \\
\hline INDIA & 28 & UNITED ARAB EMIRATES & 1 \\
\hline INDONESIA & 17 & UNITED KINGDOM & 91 \\
\hline IRELAND & 20 & USA & 138 \\
\hline ITALY & 140 & VENEZUELA & 28 \\
\hline JAMAICA & 6 & VIETNAM & 14 \\
\hline JAPAN & 26 & Total & 1569 \\
\hline
\end{tabular}




\begin{tabular}{|c|c|c|c|c|c|c|c|c|c|c|c|}
\hline \multicolumn{12}{|l|}{$\begin{array}{l}\text { TABLE A2 } \\
\text { CORRELATION MATRIX }\end{array}$} \\
\hline & Assets & Equity & $\begin{array}{l}\text { Asset } \\
\text { Growth }\end{array}$ & $\left|\begin{array}{c}\text { Return } \\
\text { on Assets }\end{array}\right|$ & $\begin{array}{l}\text { Return } \\
\text { on } \\
\text { Equity }\end{array}$ & $\begin{array}{c}\text { Overhead } \\
\text { Costs/Income }\end{array}$ & Equity/Assets & $\begin{array}{c}\text { Real } \\
\text { GDP } \\
\text { Growth }\end{array}$ & Concentration & Inflation & $\begin{array}{c}\text { Recurring } \\
\text { Earning } \\
\text { Power }\end{array}$ \\
\hline Assets & 1.000 & & & & & & & & & & \\
\hline Equity & 0.952 & 1.000 & & & & & & & & & \\
\hline Asset Growth & 0.014 & 0.012 & 1.000 & & & & & & & & \\
\hline Return on Assets & 0.009 & 0.013 & 0.079 & 1.000 & & & & & & & \\
\hline Return on Equity & 0.011 & 0.012 & 0.096 & 0.528 & 1.000 & & & & & & \\
\hline Overhead Costs/Income & -0.003 & -0.003 & 0.011 & 0.006 & 0.007 & 1.000 & & & & & \\
\hline Equity/Assets & -0.025 & -0.011 & -0.185 & 0.095 & -0.076 & 0.000 & 1.000 & & & & \\
\hline Real GDP Growth & 0.035 & 0.038 & 0.127 & 0.005 & 0.096 & 0.004 & -0.111 & 1.000 & & & \\
\hline Concentration & 0.014 & 0.009 & 0.087 & -0.011 & 0.000 & 0.008 & 0.034 & -0.005 & 1.000 & & \\
\hline Inflation & 0.079 & 0.044 & 0.050 & 0.072 & 0.043 & 0.021 & 0.089 & -0.177 & 0.124 & 1.000 & \\
\hline Recurring Earning Power & 0.007 & 0.012 & 0.049 & 0.790 & 0.376 & 0.003 & 0.143 & -0.040 & -0.045 & 0.124 & 1.000 \\
\hline
\end{tabular}




\begin{tabular}{|c|c|c|c|c|c|}
\hline \multicolumn{6}{|c|}{$\begin{array}{l}\text { TABLE A3 } \\
\text { COMPARISON OF BANK C }\end{array}$} \\
\hline & & \multicolumn{2}{|c|}{ Our Sample } & \multicolumn{2}{|c|}{ World Bank Sample } \\
\hline & Statistics & Return on Assets & Return on Equity & Return on Assets & Return on Equity \\
\hline \multirow{5}{*}{ 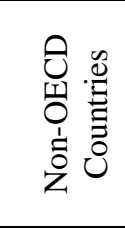 } & Mean & 1.68 & 11.85 & 1.31 & 11.92 \\
\hline & Std. Deviation & 5.36 & 36.46 & 2.12 & 11.14 \\
\hline & Maximum & 73.17 & 615.39 & 8.57 & 57.65 \\
\hline & Minimum & -111.13 & -927.38 & -13.66 & -50.55 \\
\hline & Observations & 2991 & 2989 & 8076 & 8076 \\
\hline \multirow{5}{*}{ 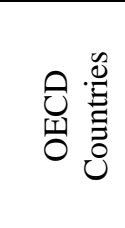 } & Mean & 0.76 & 8.58 & 1.01 & 10.30 \\
\hline & Std. Deviation & 4.30 & 26.64 & 0.74 & 6.15 \\
\hline & Maximum & 73.01 & 558.26 & 5.95 & 102.70 \\
\hline & Minimum & -82.58 & -321.46 & -8.48 & -124.22 \\
\hline & Observations & 4729 & 4710 & 35033 & 35033 \\
\hline \multirow{5}{*}{ 胥 } & Mean & 1.11 & 9.85 & 1.06 & 10.61 \\
\hline & Std. Deviation & 4.76 & 30.87 & 1.14 & 7.38 \\
\hline & Maximum & 73.17 & 615.39 & 8.57 & 102.70 \\
\hline & Minimum & -111.13 & -927.38 & -13.66 & -124.22 \\
\hline & Observations & 7720 & 7699 & 43109 & 43109 \\
\hline
\end{tabular}




\begin{tabular}{|c|c|c|c|c|c|c|}
\hline \multicolumn{7}{|c|}{$\begin{array}{l}\text { TABLE A4 } \\
\text { TESTS FOR NORMALITY OF LOGARITHMIC BANK SIZE }\end{array}$} \\
\hline & \multicolumn{3}{|c|}{ Non-OECD Countries } & \multicolumn{3}{|c|}{ OECD Countries } \\
\hline Year & Skewness & Kurtosis & \begin{tabular}{|c}
$\begin{array}{c}\text { Jarque-Bera Test } \\
\text { Statistic }\end{array}$ \\
\end{tabular} & Skewness & Kurtosis & $\begin{array}{c}\text { Jarque-Bera Test } \\
\text { Statistic } \\
\end{array}$ \\
\hline 1997 & -0.25 & 4.05 & 12.23 & 0.41 & 4.21 & 34.25 \\
\hline 1998 & -0.14 & 3.85 & 6.39 & 0.64 & 3.56 & 25.15 \\
\hline 1999 & -0.30 & 3.58 & 5.62 & 0.92 & 4.75 & 73.31 \\
\hline 2000 & -0.15 & 3.62 & 4.35 & 0.78 & 4.81 & 60.96 \\
\hline 2001 & -0.43 & 3.59 & 11.29 & 0.82 & 5.24 & 90.03 \\
\hline 2002 & -0.24 & 4.05 & 15.15 & 0.63 & 4.41 & 46.29 \\
\hline 2003 & -0.14 & 4.76 & 37.41 & 0.64 & 4.25 & 42.92 \\
\hline 2004 & 0.35 & 4.15 & 25.76 & 0.19 & 3.31 & 6.15 \\
\hline 2005 & 0.56 & 3.88 & 32.29 & 0.20 & 3.52 & 13.10 \\
\hline 2006 & 0.44 & 3.75 & 20.07 & 0.14 & 3.20 & 3.37 \\
\hline 2007 & 0.49 & 3.79 & 21.35 & 0.15 & 3.35 & 5.49 \\
\hline
\end{tabular}




\section{CESifo Working Paper Series}

for full list see www.cesifo-group.org/wp

(address: Poschingerstr. 5, 81679 Munich, Germany, office@cesifo.de)

2709 Jon H. Fiva and Gisle James Natvik, Do Re-election Probabilities Influence Public Investment?, July 2009

2710 Jarko Fidrmuc and Iikka Korhonen, The Impact of the Global Financial Crisis on Business Cycles in Asian Emerging Economies, July 2009

2711 J. Atsu Amegashie, Incomplete Property Rights and Overinvestment, July 2009

2712 Frank R. Lichtenberg, Response to Baker and Fugh-Berman's Critique of my Paper, "Why has Longevity Increased more in some States than in others?", July 2009

2713 Hans Jarle Kind, Tore Nilssen and Lars Sørgard, Business Models for Media Firms: Does Competition Matter for how they Raise Revenue?, July 2009

2714 Beatrix Brügger, Rafael Lalive and Josef Zweimüller, Does Culture Affect Unemployment? Evidence from the Röstigraben, July 2009

2715 Oliver Falck, Michael Fritsch and Stephan Heblich, Bohemians, Human Capital, and Regional Economic Growth, July 2009

2716 Wladimir Raymond, Pierre Mohnen, Franz Palm and Sybrand Schim van der Loeff, Innovative Sales, R\&D and Total Innovation Expenditures: Panel Evidence on their Dynamics, July 2009

2717 Ben J. Heijdra and Jochen O. Mierau, Annuity Market Imperfection, Retirement and Economic Growth, July 2009

2718 Kai Carstensen, Oliver Hülsewig and Timo Wollmershäuser, Price Dispersion in the Euro Area: The Case of a Symmetric Oil Price Shock, July 2009

2719 Katri Kosonen and Gaëtan Nicodème, The Role of Fiscal Instruments in Environmental Policy, July 2009

2720 Guglielmo Maria Caporale, Luca Onorante and Paolo Paesani, Inflation and Inflation Uncertainty in the Euro Area, July 2009

2721 Thushyanthan Baskaran and Lars P. Feld, Fiscal Decentralization and Economic Growth in OECD Countries: Is there a Relationship?, July 2009

2722 Nadia Fiorino and Roberto Ricciuti, Interest Groups and Government Spending in Italy, 1876-1913, July 2009

2723 Andreas Wagener, Tax Competition, Relative Performance and Policy Imitation, July 2009 
2724 Hans Fehr and Fabian Kindermann, Pension Funding and Individual Accounts in Economies with Life-cyclers and Myopes, July 2009

2725 Ernesto Reuben and Arno Riedl, Enforcement of Contribution Norms in Public Good Games with Heterogeneous Populations, July 2009

2726 Kurt Schmidheiny and Marius Brülhart, On the Equivalence of Location Choice Models: Conditional Logit, Nested Logit and Poisson, July 2009

2727 Bruno S. Frey, A Multiplicity of Approaches to Institutional Analysis. Applications to the Government and the Arts, July 2009

2728 Giovanni Villani, A Strategic R\&D Investment with Flexible Development Time in Real Option Game Analysis, July 2009

2729 Luca Di Corato and Michele Moretto, Investing in Biogas: Timing, Technological Choice and the Value of Flexibility from Inputs Mix, July 2009

2730 Gilad D. Aharonovitz, Nathan Skuza and Faysal Fahs, Can Integrity Replace Institutions? Theory and Evidence, July 2009

2731 Michele Moretto and Sergio Vergalli, Managing Migration through Conflicting Policies: an Option-theory Perspective, July 2009

2732 Volker Nitsch, Fly or Cry: Is Airport Noise Costly?, July 2009

2733 Francesco Cinnirella and Joachim Winter, Size Matters! Body Height and Labor Market Discrimination: A Cross-European Analysis, July 2009

2734 Samuel Bowles and Sandra Polanía Reyes, Economic Incentives and Social Preferences: A Preference-based Lucas Critique of Public Policy, July 2009

2735 Gary Burtless, Lessons of the Financial Crisis for the Design of National Pension Systems, July 2009

2736 Helmuth Cremer, Firouz Gahvari and Pierre Pestieau, Fertility, Human Capital Accumulation, and the Pension System, July 2009

2737 Hans Jarle Kind and Frank Stähler, Market Shares in Two-Sided Media Industries, July 2009

2738 Pamela Campa, Alessandra Casarico and Paola Profeta, Gender Culture and Gender Gap in Employment, August 2009

2739 Sebastian Gechert, Supplementary Private Health Insurance in Selected Countries: Lessons for EU Governments?, August 2009

2740 Leif Danziger, Endogenous Monopsony and the Perverse Effect of the Minimum Wage in Small Firms, August 2009 
2741 Yan Dong and John Whalley, A Third Benefit of Joint Non-OPEC Carbon Taxes: Transferring OPEC Monopoly Rent, August 2009

2742 Valentina Bosetti, Carlo Carraro and Massimo Tavoni, Climate Change Mitigation Strategies in Fast-Growing Countries: The Benefits of Early Action, August 2009

2743 Christina Felfe, The Willingness to Pay for Job Amenities: Evidence from Mothers' Return to Work, August 2009

2744 Jörg Franke, Christian Kanzow, Wolfgang Leininger and Alexandra Väth, Effort Maximization in Asymmetric N-Person Contest Games, August 2009

2745 Bruno S. Frey and Paolo Pamini, Making World Heritage Truly Global: The Culture Certificate Scheme, August 2009

2746 Frank N. Caliendo, Is Social Security behind the Collapse of Personal Saving?, August 2009

2747 Caterina Liesegang and Marco Runkel, Corporate Income Taxation of Multinationals and Fiscal Equalization, August 2009

2748 Chrysovalantou Milliou and Apostolis Pavlou, Upstream Horizontal Mergers and Efficiency Gains, August 2009

2749 Rüdiger Pethig and Christian Wittlich, Interaction of Carbon Reduction and Green Energy Promotion in a Small Fossil-Fuel Importing Economy, August 2009

2750 Kai Carstensen, Oliver Hülsewig and Timo Wollmershäuser, Monetary Policy Transmission and House Prices: European Cross-country Evidence, August 2009

2751 Olaf Posch, Explaining Output Volatility: The Case of Taxation, August 2009

2752 Beatrice Scheubel, Daniel Schunk and Joachim Winter, Don't Raise the Retirement Age! An Experiment on Opposition to Pension Reforms and East-West Differences in Germany, August 2009

2753 Daniel G. Arce, Dan Kovenock and Brian Roberson, Suicide Terrorism and the Weakest Link, August 2009

2754 Mario Larch and Wolfgang Lechthaler, Comparative Advantage and Skill-Specific Unemployment, August 2009

2755 Horst Raff and Nicolas Schmitt, Buyer Power in International Markets, August 2009

2756 Seppo Kari, Hanna Karikallio and Jukka Pirttilä, The Impact of Dividend Taxation on Dividends and Investment: New Evidence Based on a Natural Experiment, August 2009

2757 Mirco Tonin and Michael Vlassopoulos, Disentangling the Sources of Pro-social Behavior in the Workplace: A Field Experiment, August 2009 
2758 Nicole Grunewald and Inmaculada Martínez-Zarzoso, Driving Factors of Carbon Dioxide Emissions and the Impact from Kyoto Protocol, August 2009

2759 Yu-Fu Chen and Michael Funke, Booms, Recessions and Financial Turmoil: A Fresh Look at Investment Decisions under Cyclical Uncertainty, August 2009

2760 Jan-Egbert Sturm and Jakob de Haan, Does Central Bank Communication really Lead to better Forecasts of Policy Decisions? New Evidence Based on a Taylor Rule Model for the ECB, August 2009

2761 Larry Karp, Sacrifice, Discounting and Climate Policy: Five Questions, August 2009

2762 Marianna Belloc and Samuel Bowles, International Trade, Factor Mobility and the Persistence of Cultural-Institutional Diversity, August 2009

2763 Charles Noussair and Fangfang Tan, Voting on Punishment Systems within a Heterogeneous Group, August 2009

2764 Birgit Bednar-Friedl and Karl Farmer, Internationally Coordinated Emission Permit Policies: An Option for Withdrawers from the Kyoto Protocol?, August 2009

2765 Pierre M. Picard and David E. Wildasin, Labor Market Pooling, Outsourcing and Labor Contracts, August 2009

2766 Stefan Voigt and Lorenz Blume, The Economic Effects of Federalism and Decentralization - A Cross-Country Assessment, August 2009

2767 David S. Jacks, Christopher M. Meissner and Dennis Novy, Trade Booms, Trade Busts, and Trade Costs, August 2009

2768 Mario Jametti and Thomas von Ungern-Sternberg, Hurricane Insurance in Florida, August 2009

2769 Alessandro Balestrino, Kind of Black: The Musicians' Labour Market in Italy, August 2009

2770 Yosr Abid Fourati and Cathal O’Donoghue, Eliciting Individual Preferences for Pension Reform, August 2009

2771 Christian Breuer and Chang Woon Nam, VAT on Intra-Community Trade and Bilateral Micro Revenue Clearing in the EU, August 2009

2772 Choudhry Tanveer Shehzad, Jakob De Haan and Bert Scholtens, Growth and Earnings Persistence in Banking Firms: A Dynamic Panel Investigation, August 2009 